\title{
Analisis Kejadian Wasting pada Balita Usia 6-59 Bulan
}

\author{
Erika, Yulia Sari ${ }^{\star}$, Wa Ode Hajrah \\ Jurusan Kebidanan Poltekkes Kemenkes Jakarta III \\ *Email korespondensi: ysyuliasari@gmail.com
}

\begin{abstract}
Article Info
ABSTRACT

Article history:

Submitted: 2020-06-29

Accepted: 2020-08-29

Published: 2020-08-31

Keywords:

Wasting, Children Aged 6-59 Months, Infectious Diseases History;

Wasting is an acute malnutrition which could indirectly increase infant mortality and morbidity. Currently, wasting was serious public health problem in Indonesia with $11,1 \%$ of prevalence. This study aimed to determine the incidence of wasting in childrens aged 6-59 months in the working area of Puskesmas Kelurahan Penjaringan I, North Jakarta from March to April, 2019. The researcher measured antropometry of children to see nutritional status based on indicator of BB/TB. A case control method, as well as purposive and accidental sampling technique, was carried out in this study. As many as 60 respondents were divided into 2 groups (30 cases group and 30 control group). The data were analyzed by using chi square test and multiple logistic regression. Infectious disease history $(p=0.031)$ and protein intake $(p=0.024)$ were associated with wasting incidence in children. Infectious diseases history was dominant factor determining of wasting in children aged 659 months in Puskesmas Kelurahan Penjaringan I, North Jakarta (OR=11.897; 95\% Cl=1.246-113.570). Fostering integrated health post by providing counseling about increasing nutrient intake especially protein intake and handling infectious diseases in children so that wasting can be handled properly.
\end{abstract}

\section{ABSTRAK}

Kata kunci:

Gizi Kurus, Balita Usia

6-59 Bulan, Riwayat

Penyakit Infeksi;

Wasting merupakan masalah malnutrisi akut yang secara tidak langsung dapat meningkatkan risiko kesakitan dan kematian pada balita. Saat ini, wasting masih menjadi masalah kesehatan masyarakat serius dengan prevalensi $11,1 \%$ di Indonesia. Tujuan: Penelitian ini bertujuan untuk mengetahui faktor-faktor yang mempengaruhi kejadian wasting pada balita usia 6-59 bulan di wilayah kerja Puskesmas Kelurahan Penjaringan I Jakarta Utara pada bulan Maret - April 2019. Metode: Peneliti mengukur antropometri balita untuk melihat status gizinya berdasarkan indikator BB/TB. Penelitian ini menggunakan case control dengan teknik pengambilan sample purposive sampling dan accidental sampling. Sampel penelitian sebanyak 60 responden yang terbagi menjadi dua kelompok yaitu 30 kelompok kasus dan 30 kelompok kontrol. Data dianalisis menggunakan uji chi square dan regresi logistik ganda. Hasil Penelitian: Hasil uji multivariat regresi logistik ganda menunjukkan adanya hubungan riwayat penyakit infeksi dengan kejadian wasting $(p=0.031)$ dan asupan protein dengan kejadian wasting $(p=0.024)$. Faktor paling dominan yang mempengaruhi kejadian wasting (gizi kurus) pada balita usia 6-59 bulan di wilayah kerja Puskesmas Kelurahan Penjaringan I adalah riwayat penyakit infeksi dengan OR $=11.897$ dan $95 \% \mathrm{Cl}=1.246-113.570$. Saran: Pembinaan posyandu dalam memberikan konseling tentang peningkatan asupan nutrisi terutama asupan protein dan penanganan penyakit infeksi pada balita agar status gizi kurus dapat tertangani dengan baik. 


\section{PENDAHULUAN}

Masa balita dianggap sebagai masa pertumbuhan dan perkembangan yang paling pesat dibandingkan dengan kelompok umur lainnya sehingga disebut windows of opportunity. Intervensi kesehatan dan gizi harus diberikan secara optimal pada periode ini untuk menjamin kelangsungan hidup dan tumbuh kembang anak. ${ }^{1}$ Indonesia termasuk dalam 17 negara yang memiliki tiga masalah gizi pada anak balita: stunting, wasting, dan kelebihan berat badan.2,3 Apabila pemberian gizi tidak diberikan secara optimal akan menimbukan masalah gizi masyarakat salah satunya wasting (gizi kurus) pada balita. Wasting (gizi kurus) sebagai bentuk kegagalan untuk mencapai pertumbuhan yang optimal diukur berdasarkan BB/TB. ${ }^{4}$ Wasting memiliki dampak besar yang dapat meningkatkan risiko kesakitan dan kematian anak. Apabila keadaan kurang gizi pada masa balita terus berlanjut, maka dapat menurunkan kecerdasan, produktifitas, kreatifitas, dan sangat berpengaruh pada kualitas SDM. ${ }^{5}$

World Health Organization (WHO) secara global memperkirakan prevalensi balita wasting sebesar 8\% (52 juta balita) dengan kasus tertinggi di Benua Asia sebesar 35 juta balita yang mengalami wasting tahun $2016 .{ }^{6}$ Indonesia merupakan salah satu negara berkembang yang memiliki masalah malnutrisi termasuk wasting. Masalah kesehatan masyarakat sudah dianggap serius bila prevalensi kurus antara $10,0-14,0 \%$, dan dianggap kritis bila $\geq 15,0 \% .{ }^{7}$ Pada tahun 2016 , secara nasional prevalensi kurus pada anak balita masih $11,1 \%$ yang artinya masalah kurus di Indonesia masih merupakan masalah kesehatan masyarakat yang serius. ${ }^{8}$ Berdasarkan hasil pemantauan status gizi tahun 2016, prevalensi wasting di DKI Jakarta sebesar $11,3 \%$. Prevalensi wasting di DKI Jakarta berada diatas nasional. Berdasarkan laporan tersebut, dari enam wilayah di DKI Jakarta tercatat prevalensi wasting tertinggi berada di wilayah Jakarta Utara sebesar $16,6 \%$ sehingga masalah gizi kurus (wasting) di Jakarta Utara termasuk kategori akut-kronis. ${ }^{8}$

Tingginya prevalensi kejadian wasting dipengaruhi oleh banyak faktor resiko seperti faktor asupan nutrisi, pendapatan keluarga, riwayat penyakit infeksi, status kelengkapan imunisasi, dan pemberian ASI eksklusif. ${ }^{9}$ Menurut Putri, dkk (2010), faktor langsung yang berhubungan dengan kejadian wasting ialah asupan karbohidrat, asupan energi, asupan protein dan asupan lemak. ${ }^{10}$ Menurut Afriyani, dkk (2016) balita yang memiliki status imunisasi tidak lengkap dan riwayat penyakit infeksi cenderung akan mengalami wasting sebesar 3,512 kali lebih besar. ${ }^{9}$ Menurut Rochmawati, dkk (2016) balita yang tidak ASI eksklusif berisiko 3,946 kali mengalami kejadian gizi kurus. ${ }^{11}$

Penelitian bertujuan untuk mengetahui faktor-faktor yang mempengaruhi kejadian wasting pada balita diantaranya riwayat penyakit infeksi, ASI Eksklusif, kelengkapan imunisasi, asupan protein dan asupan karbohidrat balita. Peneliti mengukur antropometri balita untuk melihat status gizinya berdasarkan indikator $\mathrm{BB} / \mathrm{TB}$.

\section{METODE PENELITIAN}

Penelitian ini dilakukan dengan pendekatan kuantitatif. Desain penelitian yang digunakan adalah case control, yaitu penelitian yang dilakukan dengan cara membandingkan antara dua kelompok yaitu kelompok kasus dan kelompok kontrol. ${ }^{12}$ Studi case control dilakukan dengan mengidentifikasi kelompok kasus dan kelompok kontrol, kemudian secara retrospektif (pengamatan terhadap peristiwa-peristiwa yang telah terjadi) diteliti melalui wawancara dan catatan dokumentasi mengenai faktor- 
faktor resiko yang mungkin dapat menerangkan apakah kelompok kasus dan kontrol dapat terkena paparan atau tidak.

Populasi kasus pada penelitian ini adalah balita usia 6-59 bulan yang mengalami wasting di wilayah kerja Puskesmas Kelurahan Penjaringan I dan populasi kontrol pada penelitian ini adalah adalah balita usia 6-59 bulan yang tidak mengalami wasting di wilayah kerja Puskesmas Kelurahan Penjaringan I. Sampel yang digunakan sebanyak 60 sampel (30 sampel untuk kelompok kasus dan 30 sampel untuk kelompok kontrol). Teknik pengambilan sampel pada kelompok kasus dilakukan dengan teknik non random sampling yaitu purposive sampling. Pengambilan sampel dilakukan secara door to door ke rumah responden dan didampingi kader dengan melihat data kejadian balita wasting pada bulan Februari 2019. Teknik pengambilan sampel pada kelompok kontrol dengan teknik non random sampling secara accidental sampling. Pengambilan sampel dilakukan dengan pengukuran status gizi secara langsung di masing-masing posyandu.

Jenis data yang dikumpulkan dalam penelitian ini berupa data primer dan data sekunder. Data primer merupakan data yang didapatkan secara langsung oleh peneliti dengan pengukuran BB dan TB pada balita secara langsung dan wawancara pada ibu balita untuk variabel penelitian riwayat penyakit infeksi, ASI eksklusif dan asupan nutrisi balita. Sedangkan data sekunder didapatkan melalui dokumentasi pencatatan yang ada di puskesmas maupun buku KIA/KMS yang dipegang ibu balita mengenai variabel kelengkapan imunisasi.

Alat pengumpulan data yang digunakan melalui teknik pengumpulan wawancara pada ibu balita yaitu dengan kuesioner pertanyaan rinci untuk variabel penelitian riwayat penyakit infeksi dan asi eksklusif. Variabel penelitian asupan nutrisi dengan teknik wawancara digunakan alat pengumpulan data formulir food recall 24 jam untuk melihat asupan nutrisi yang dikonsumsi balita selama 24 jam terakhir. Kesioner penelitian yang digunakan yaitu kuesioner riset kesehatan dasar tahun 2013. Penilain data wasting menggunakan z-score, sedangkan pengolahan data statistik menggunakan program software uji statistik. Analisis data yang digunakan yaitu analisis univariat, analisis bivariat (chi square) dan analisis multivariat (regresi logistik ganda). Penelitian sudah dilakukan kaji etik di komisi etik Poltekkes Kemenkes Jakarta III dengan menerapkan prinsip etika beneficience, menghargai hak asasi manusia, dan informed consent kepada calon responden penelitian dengan nomor KEPKPKKJ3/142/IV/2019.

\section{HASIL PENELITIAN}

Hasil Penelitian dapat disajikan sebagai berikut:

Tabel 1. Distribusi Frekuensi Karakteristik Responden Berdasarkan Jenis Kelamin dan Usia Balita

\begin{tabular}{lcc}
\hline \multicolumn{1}{c}{ Karakterisrik } & Jumlah & Persentase (\%) \\
\hline $\begin{array}{l}\text { Jenis Kelamin } \\
\text { Laki-Laki }\end{array}$ & 30 & 50 \\
Perempuan & 30 & 50 \\
\hline Usia & 38 & \\
6-24 Bulan & 11 & 63.3 \\
25-36 Bulan & 11 & 18.3 \\
37-59 Bulan & 18.3 \\
\hline
\end{tabular}


Tabel 2 Hubungan Pemberian ASI, Kelengkapan Imunisasi, Riwayat Penyakit Infeksi, Asupan Protein dan Asupan Karbohidrat terhadap Kejadian Wasting

\begin{tabular}{|c|c|c|c|c|c|c|c|}
\hline \multirow{3}{*}{ Variabel } & \multicolumn{4}{|c|}{ Kejadian Wasting } & \multirow{3}{*}{$\begin{array}{c}P \\
\text { value }\end{array}$} & \multirow{3}{*}{ OR } & \multirow{3}{*}{ Cl $95 \%$} \\
\hline & \multicolumn{2}{|c|}{ Kasus } & \multicolumn{2}{|c|}{ Kontrol } & & & \\
\hline & $\mathbf{n}$ & $\%$ & $n$ & $\%$ & & & \\
\hline \multicolumn{8}{|l|}{ Pemberian ASI } \\
\hline $\mathrm{Ya}$ & 9 & 30 & 14 & 46.7 & 0,288 & 2,04 & $0,7-5,9$ \\
\hline Tidak & 21 & 70 & 16 & 53.3 & & & \\
\hline \multicolumn{8}{|l|}{ Kelengkapan } \\
\hline Imunisasi & 25 & 83.3 & 25 & 83.3 & 1,000 & 1,00 & $0,3-3,9$ \\
\hline Lengkap & 5 & 16.7 & 5 & 16.7 & & & \\
\hline \multicolumn{8}{|l|}{ Tidak Lengkap } \\
\hline \multicolumn{8}{|l|}{ Riwayat Penyakit } \\
\hline Infeksi & 29 & 96.7 & 23 & 76.7 & 0,023 & 8,8 & $1,0-$ \\
\hline Ada & 1 & 3.3 & 7 & 23.3 & & & 76,9 \\
\hline \multicolumn{8}{|l|}{ Tidak } \\
\hline \multicolumn{8}{|l|}{ Asupan Protein } \\
\hline Tercukupi & 13 & 43.3 & 21 & 70 & 0,068 & 3,1 & $1,1-8,8$ \\
\hline Tidak Tercukupi & 17 & 56.7 & 9 & 30 & & & \\
\hline \multicolumn{8}{|l|}{ Asupan } \\
\hline Karbohidrat & 8 & 26.7 & 16 & 53.3 & 0,065 & 3,1 & $1,1-9,3$ \\
\hline Tercukupi & 22 & 73.3 & 14 & 46.7 & & & \\
\hline Tidak Tercukupi & & & & & & & \\
\hline
\end{tabular}

Tabel 3 Hasil Analisis Multivariat

\begin{tabular}{lcccc}
\hline \multicolumn{1}{c}{ Variabel } & $\begin{array}{c}\boldsymbol{p} \\
\text { value }\end{array}$ & SE & OR & CI 95\% \\
& & & & \\
\hline Riwayat Penyakit Infeksi & 0.031 & 1,2 & 11.897 & $\begin{array}{c}1.246- \\
\end{array}$ \\
& 0.024 & 0,6 & 3.801 & $1.192-12.126$ \\
\hline Asupan Protein & & & & \\
\hline
\end{tabular}

Berdasarkan tabel 3 variabel yang berpengaruh signifikan terhadap kejadian wasting pada balita yaitu riwayat penyakit infeksi dan asupan protein. Faktor paling dominan yang mempengaruhi kejadian wasting (gizi kurus) pada balita usia 6-59 bulan di wilayah kerja Puskesmas Kelurahan Penjaringan I adalah riwayat penyakit infeksi dengan $\mathrm{OR}=11.897$. Balita yang memiliki riwayat penyakit infeksi berpeluang 11,897 kali mengalami gizi kurus setelah di kontrol variabel asupan protein pada kelompok yang sama. Balita yang asupan proteinnya tidak tercukupi berpeluang 3,801 kali mengalami gizi kurus setelah di kontrol variabel riwayat penyakit infeksi pada kelompok yang sama.

\section{PEMBAHASAN}

Berdasarkan hasil analisis multivariat, riwayat penyakit infeksi merupakan faktor dominan yang berpengaruh terhadap kejadian wasting (gizi kurus) pada Balita usia 6-59 bulan di wilayah kerja Puskesmas Kelurahan Penjaringan I. Hal ini sejalan 
dengan penelitian yang dilakukan oleh Rochmawati, dkk (2016) balita yang mengalami penyakit infeksi berpeluang 5,714 kali mengalami wasting. ${ }^{11}$ Status gizi dengan kejadian infeksi mempunyai keterkaitan yang erat. Anak yang mempunyai status gizi kurang mudah terkena infeksi, karena anak tidak mempunyai daya tahan tubuh yang cukup. Sebaliknya anak yang menderita infeksi tidak mempunyai nafsu makan yang cukup, akibatnya anak kekurangan gizi dan jatuh pada status gizi kurang. Penyakit infeksi juga dapat disebabkan oleh kurangnya layanan kesehatan pada masyarakat, keadaan lingkungan yang tidak sehat, pengolahan pemberian nutrisi yang tidak higienis, pemberian makanan pendamping ASI lebih awal, dan pola asuh yang kurang baik, misalnya anak dibiarkan bermain pada tempat kotor. ${ }^{13}$

Penyakit infeksi seperti diare, pneumonia, dan malaria adalah penyebab sebagian besar kematian. Setengah dari 5,9 juta anak balita meninggal karena penyakit infeksi. Berdasarkan hasil penelitian didapatkan dari total sampel balita gizi kurus, $76,7 \%$ balita diantaranya memiliki riwayat penyakit infeksi dalam sebulan terakhir dengan diagnosis ISPA dan diare. Hasil regresi logistik ganda yang dilakukan oleh Namangboling dkk (2017) menunjukkan variabel yang paling dominan berhubungan serta mempunyai pengaruh terhadap status gizi adalah riwayat penyakit infeksi $(p=0,025$, OR:2,38). Dari total sampel, 58,6\% anak yang mempunyai riwayat penyakit infeksi, seperti diare dan ISPA, masuk dalam kelompok sampel dengan kategori status gizi kurus dan sangat kurus. ${ }^{14} \mathrm{Hal}$ ini sejalan juga dengan penelitian yang dilakukan Tenry, dkk (2014), balita yang mengalami diare berpeluang 14,37 kali mengalami wasting. Balita yang mengalami ISPA berpeluang 5,32 kali mengalami wasting. ${ }^{15}$

ISPA merupakan salah satu penyakit infeksi yang erat kaitannya dengan masalah gizi. Tanda dan gejala penyakit ISPA ini bermacam-macam antara lain batuk, kesulitan bernafas, tenggorakan kering, pilek, demam dan sakit telinga. ISPA disebabkan lebih dari 300 jenis bakteri, virus dan riketsia. ${ }^{16}$ Berbagai hasil studi menunjukan terjadinya penurunan berat badan anak setiap hari selama ISPA berlangsung. Diperkirakan panas yang menyertai ISPA memegang peranan penting dalam penurunan asupan nutrien karena menurunnya nafsu makan anak. ${ }^{17}$

Diare menjadi penyebab penting bagi kekurangan gizi yang disebabkan adanya anoreksia pada penderita diare, sehingga anak makan lebih sedikit daripada biasanya dan kemampuan menyerap sari makanan juga berkurang. Disisi lain kebutuhan tubuh akan makanan meningkat akibat dari adanya infeksi. Setiap kejadian diare dapat menyebabkan kekurangan gizi, sehingga bila kejadinnya berkepanjangan maka berdampak terhadap pertumbuhan anak akan menurun. ${ }^{18}$

Balita yang asupan proteinnya tidak tercukupi berpeluang 3,801 kali mengalami gizi kurus setelah dikontrol variabel riwayat penyakit infeksi pada kelompok yang sama. Hasil analisis multivariat tersebut yang dilakukan sejalan dengan penelitian yang telah dilakukan sebelumnya oleh Dwi Sisca dkk (2010) yang menunjukkan ada hubungan bermakna antara asupan protein dengan kejadian wasting $(p=0.038)$ pada anak umur $24-59$ bulan. ${ }^{10}$

Protein merupakan molekul makro yang terdiri atas rantai-rantai panjang asam amino, yang terikat satu sama lain dalam ikatan peptida. Berdasarkan kemampuan tubuh dalam mensintesis, asam amino terbagi ke dalam dua kelompok besar, yaitu esensial berarti tidak dapat disintesis tubuh dan harus didapatkan dari makanan yang dikonsumsi, sedangkan non-esensial berarti dapat dibuat di dalam tubuh dari pemecahan jaringan yang rusak dan dari kelebihan asam amino esensial. Protein 
dalam tubuh secara bergantian dipecah (katabolisme) dan disintesis kembali (anabolisme). Protein mempunyai fungsi khas yaitu membangun, memelihara sel-sel dan jaringan tubuh. Sebelum menjalankan fungsinya sebagai zat pembangun, asamasam amino esensial yang diperlukan harus tersedia terlebih dahulu. Pertumbuhan atau penambahan sel baru bisa dilakukan jika telah cukup tersedia gabungan asam amino yang sesuai dalam segi jenis dan jumlah. ${ }^{19,20}$

Protein juga memiliki fungsi utama membentuk antibodi. Tingginya tingkat kematian pada anak-anak yang menderita gizi kurang kebanyakan disebabkan oleh menurunnya daya tahan tubuh karena ketidakmampuannya membentuk antibodi dalam jumlah yang cukup. ${ }^{19}$ Kemampuan tubuh untuk menangkal serangan toksik dan melakukan detoksifikasi sangat tergantung pada enzim-enzim yang terdapat di dalam hati. Dalam keadaan kekurangan protein maka pembentukan enzim tersebut akan terhambat sehingga menjadi rentan terhadap penyakit. ${ }^{20}$ Asam amino yang berperan membentuk antibodi adalah glisin. Glisin mengikat bahan-bahan toksik dan mengubahnya menjadi bahan tidak berbahaya. Akibat kekurangan protein sistem imunitas dan antibodi berkurang, sehingga anak mudah terserang penyakit seperti pilek, batuk, diare atau penyakit infeksi yang lebih berat. Kekurangan protein ini banyak terdapat pada masyarakat sosial ekonomi rendah. ${ }^{13,21}$

Asupan karbohidrat merupakan faktor risiko dari kejadian gizi kurus dan balita yang kurang mengkonsumsi asupan karbohidrat berpeluang 3,143 kali mengalami kejadian gizi kurus dibandingkan dengan balita yang tidak kurang mengkonsumsi asupan karbohidrat. Hal ini sejalan dengan penelitian Rochmawati dkk (2016) yang menunjukkan bahwa tidak ada hubungan antara asupan karbohidrat dengan kejadian wasting. ${ }^{11}$

Asupan makanan merupakan zat gizi yang dikonsumsi oleh tubuh untuk beraktivitas serta mencapai kesehatan yang optimal. Energi memiliki fungsi sebagai penunjang proses pertumbuhan, metabolism tubh dan proses aktivitas fisik. Energi yang dibutuhkan berasal dari zat gizi makro yang dikonsumsi seperti karbohidrat, protein dan lemak. ${ }^{5}$ Karbohidrat memang zat gizi makro yang berperan sebagai sumber energi utama karena 60-80\% dari kebutuhan energi dipenuhi oleh karbohidrat. ${ }^{13}$ Namun karbohidrat bukan satu-satunya zat gizi yang dapat menghasilkan energi. Energi lainnya bisa didapatkan dari lemak dan protein.

Metode yang digunakan dalam menanyakan tingkat asupan zat gizi balita menggunakan food recall yang bergantung pada ingatan responden (ibu balita) sehingga bisa meningkatkan terjadinya bias dalam melaporkan bahan makanan yang dikonsumsi balita selama 24 jam terakhir. Hal tersebut dapat diminimalisir dengan menggunakan alat bantu seperti buku gambar makanan atau food model pada saat wawancara.

Berdasarkan hasil analisis bivariat menunjukkan tidak terdapat hubungan antara ASI Eksklusif terhadap kejadian wasting pada balita $(p=0.228)$ dan diperoleh nilai OR = 2,042 (CI 95\%) artinya ASI Eksklusif merupakan faktor risiko dari kejadian gizi kurus dan balita yang tidak ASI Eksklusif berpeluang 2,042 kali mengalami kejadian gizi kurus dibandingkan dengan balita yang ASI Eksklusif. Hal ini dikarenakan sejalan dengan bertambahnya usia balita kebutuhan nutrisi baik makronutrien maupun mikronutrien tidak hanya di dapatkan dari ASI saja. Selain itu, keterampilan makan (oromotor skills) terus berkembang dan balita mulai memperlihatkan minat terhadap makanan lain selain yang berbentuk susu (ASI dan susu formula). ${ }^{22}$ Namun, ASI saja 
tetap penting diberikan pada balita hingga 6 bulan dan dapat dilanjutkan hingga dua tahun dengan tambahan MP-ASI.

Hasil analisis dari 60 responden pada kelompok kasus yang tidak ASI Eksklusif lebih besar (70,0\%) dibandingkan dengan balita pada kelompok kontrol (53,3\%). ASI mengandung zat gizi yang paling sesuai dalam memenuhi kebutuhan gizi bayi untuk tumbuh kembang optimal. ASI mudah dicerna, diserap dan digunakan secara efisien oleh tubuh bayi. ASI melindungi bayi dari kejadian infeksi. ${ }^{23}$

Berdasarkan penelitian Efrata Girma dkk (2018) kemungkinan wasting adalah $60 \%$ lebih tinggi untuk balita yang mulai menyusu antara 1 dan 24 jam kelahiran daripada balita lainnya. ${ }^{24}$ Beberapa hari pertama setelah persalinan, ASI memproduksi cairan emas, cairan pelindung yang kaya zat anti infeksi dan berprotein tinggi yang disebut kolostrum. ${ }^{23}$ Kolostrum lebih banyak mengandung protein dan zat anti infeksi 10-17 kali lebih banyak dibanding ASI matang (mature). Cairan emas yang encer dan berwarna kuning atau jernih yang lebih menyerupai darah daripada susu, sebab mengandung sel hidup yang menyerupai sel darah putih yang dapat membunuh kuman penyakit. ${ }^{21} \mathrm{Hal}$ ini menunjukkan balita yang tidak ASI Eksklusif antibodinya berkurang sehingga rentan mengalami penyakit infeksi yang mengakibatkan penurunan nafsu makan dan berdampak pada status gizi kurus balita.

Berdasarkan hasil analisis bivariat menunjukkan tidak terdapat hubungan antara kelengkapan imunisasi terhadap kejadian wasting pada balita $(p=1.000)$ dan diperoleh nilai $\mathrm{OR}=1,000(\mathrm{Cl} 95 \%)$ artinya kelengkapan imunisasi merupakan faktor risiko dari kejadian gizi kurus dan balita yang imunisasi tidak lengkap berpeluang 1,000 kali mengalami kejadian gizi kurus dibandingkan dengan balita imunisasi lengkap. Hal ini sejalan dengan penelitian Hendrayati dkk (2012) yang menunjukkan bahwa tidak ada hubungan antara kelengkapan dengan kejadian wasting $(p=0,567) .{ }^{5}$

Imunisasi adalah adalah salah satu usaha memberikan kekebalan tubuh bayi dan anak terhadap suatu penyakit tertentu. Hasil penelitian menujukkan bahwa status imunisasi balita sudah baik. Imunisasi bukan penyebab langsung dari masalah gizi. Imunisasi yang tidak lengkap akan berdampak timbul penyakit infeksi untuk jangka panjang. Balita yang tidak diimunisasi akan lebih mudah terkena penyakit infeksi seperti TBC, difteri, tetanus, pertusis, hepatitis B, Haemophillus influenza tipe B, campak, dan sebagainya. Meskipun status imunisasi balita sudah lengkap, namun keadaan lingkungan yang tidak memadai dan asupan makanan kurang maka balita akan mudah terkena penyakit infeksi. ${ }^{5}$

\section{SIMPULAN DAN SARAN}

Berdasarkan hasil penelitian maka dapat disimpulkan bahwa terdapat hubungan antara riwayat penyakit infeksi dan asupan protein dengan kejadian wasting pada Balita, dimana riwayat penyakit infeksi merupakan factor yang paling dominan terhadap kejadian wasting pada balita usia 6-59 bulan, namun penelitian ini juga mendapatkan bahwa tidak terdapat hubungan antara pemberian ASI, kelengkapan imunisasi serta asupan karbohidrat terhadap kejadian wasting pada balita usia 6-59 bulan.

Berdasarkan hasil penelitian diatas perlu adanya peningkatan pengawasan oleh tenaga kesehatan terhadap status gizi balita yang dilihat dari penyakit infeksi dan asupan nutrisi yang dikonsumsi balita. Pengawasan tersebut diantaranya pembinaan posyandu dengan memberikan konseling terutama mengenai penyakit infeksi pada balita dan asupan nutrisi tinggi protein, menilai keadaan balita yang mengunjungi 
fasilitas pelayanan kesehatan maupun kegiatan di luar faskes seperti posyandu setiap bulan, komunikasi dan kerjasama secara intensif dengan kader penting dilakukan untuk menjangkau balita yang tidak pernah mengunjungi tenaga kesehatan agar status gizi nya tetap terpantau.

Puskesmas sebagai fasilitas kesehatan dasar perlu melakukan kerjasama lintas program antara KIA dan Gizi dalam pembinaan posyandu dengan menggalakkan penyuluhan di setiap kegiatan posyandu balita mengenai pemberian makanan balita yang seimbang sesuai usia kebutuhan bayi terutama peningkatanan nutrisi tinggi protein dan pertolongan pertama pada balita yang mengalami penyakit infeksi. Penyuluhan sebagai upaya promotif dan preventif bagi balita dengan status gizi normal serta sebagai upaya kuratif dan rehabilitatif bagi balita dengan status gizi kurus. Hal utama yang terpenting yaitu peran seluruh anggota keluarga dengan meningkatkan pemahaman, tindakan dan kesadaran orangtua mengenai gizi balita. Hal-hal dapat dilakukan diantaranya rutin mengunjungi posyandu setiap bulan sehingga status gizi balita dapat terpantau dengan baik dan tercipta keluarga mandiri sadar gizi, peningkatan bahan makanan tinggi protein (ikan, ayam, telur, kacangkacangan), pembuatan bahan makanan yang bervariasi agar tidak memperburuk kejadian gizi kurus pada balita dan pengolahan makanan yang higienis.

Penelitian selajutnya diharapkan menggunakan alat bantu seperti buku gambar makanan atau food model pada saat wawancara mengenai asupan nutrisi dengan food recall 24 jam agar tidak terjadi bias informasi takaran nutrisi yang dikonsumsi balita, pengambilan data pada kelompok kasus dan kelompok kontrol dilakukan pada hari yang sama untuk mencegah bias informasi antar responden pada kedua kelompok tersebut, dan meneliti faktor lainnya yang mempengaruhi kejadian wasting (gizi kurus) pada balita seperti jumlah saudara kandung balita dalam keluarga dengan metode yang sama ataupun metode yang berbeda

\section{DAFTAR PUSTAKA}

1. Soetjiningsih. Tumbuh Kembang Anak. 2nd ed. Jakarta: EGC; 2017.

2. Rahmawati VE, Pamungkasari EP, Murti B. Determinants of Stunting and Child Development in Jombang District. J Matern Child Heal [Internet]. 2018;03(01):68-80. Available from: http://thejmch.com/index.php?journal=thejmch\&page=article\&op=view\&path\%5B\%5D $=81 \&$ path $\% 5 \mathrm{~B} \% 5 \mathrm{D}=91$

3. Ramadhan K. Status Gizi menurut Tinggi Badan per Umur pada Balita. Poltekita J IImu Kesehat. 2020 Apr 27;13(2):96-101.

4. Badan Perencanaan Pembangunan Nasional. Rencana Aksi Nasional Pangan dan Gizi (RAN-PG) Tahun 2011-2015 [Internet]. Jakarta: Badan Perencanaan Pembangunan Nasional; $2011 . \quad 1-86 \quad$ p. Available from: https://www.bappenas.go.id/files/4613/5228/2360/ran-pg-2011-2015.pdf

5. Hendrayati, Amir A, Darmawati. Faktor Yang Mempengaruhi Kejadian Wasting Pada. Media Gizi Pangan. 2013;XV(1):56-61.

6. International Food Policy Research Institute. Global Nutrition Report 2016: From Promise to Impact: Ending Malnutrition by 2030. Global Nutrition Report - From promise to impact: ending malnutrition by 2030 . Washington, DC.: International Food Policy Research Institute; 2016. 11-14 p.

7. Kementerian Kesehatan R.I. Riset Kesehatan Dasar 2013. Jakarta: Kementerian Kesehatan R.I.; 2013.

8. Direktorat Gizi Masyarakat Kementerian Kesehatan R.I. Buku Saku Hasil Pemantauan Status Gizi (PSG) tahun 2017. Jakarta: Kementerian Kesehatan R.I.; 2018. 
9. Afriyani R, Malahayati N, Hartati H. Faktor-faktor yang Mempengaruhi Kejadian Wasting pada Balita Usia 1-5 Tahun di Puskesmas Talang Betutu Kota Palembang. J Kesehat [Internet]. 2016 Apr 30;7(1):66. Available from: http://ejurnal.poltekkestjk.ac.id/index.php/JK/article/view/120

10. Putri DSK, Wahyono TYM. Faktor Langsung dan Tidak Langsung yang Berhubungan dengan Kejadian Wasting pada Anak Umur 6 - 59 Bulan Di Indonesia Tahun 2010. Media Heal Res Dev. 2013;23(3 Sep):110-21.

11. Rochmawati, Marlenywati, Waliyo E. Gizi Kurus ( Wasting ) Pada Balita Di Wilayah Kerja Puskesmas Kota Pontianak. Vokasi Kesehat [Internet]. 2016;II(2):132-8. Available from: pontianak.ac.id/index.php/JVK/article/view/68/60

12. Notoatmodjo S. Metodologi Kesehatan. Jakarta: Rineka Cipta; 2010.

13. Harjatmo TP, Par'i HM, Wiyono S. Bahan Ajar Gizi : Penilaian Status Gizi. Jakarta: Badan PPSDM Kementerian Kesehatan R.I.; 2017.

14. Namangboling AD, Murti B, Sulaeman ES. Hubungan Riwayat Penyakit Infeksi dan Pemberian ASI Eksklusif dengan Status Gizi Anak Usia 7-12 Bulan di Kecamatan Kelapa Lima Kota Kupang. Sari Pediatr [Internet]. 2017 Nov 27;19(2):91. Available from: https://saripediatri.org/index.php/sari-pediatri/article/view/1208

15. Abeng AT, Ismail D, Huriyati E. Sanitasi, infeksi, dan status gizi anak balita di Kecamatan Tenggarong Kabupaten Kutai Kartanegara. J Gizi Klin Indones [Internet]. 2014 Jan 30;10(3):159. Available from: https://jurnal.ugm.ac.id/jgki/article/view/18867

16. Kementerian Kesehatan R.I. Pedoman Pengendalian Infeksi Saluran Pernafasan Akut. Jakarta: Dirjen PPM dan PLP Kementerian Kesehatan R.I.; 2011.

17. Wardani SM. Faktor-Faktor yang Mempengaruhi Status Gizi Balita di RW 006 Kelurahan Pancoran Mas Kecamatan Pancoran Mas Depok. Universitas Indonesia; 2012.

18. Departemen Kesehatan R.I. Buku Ajar Diare. Jakarta: Departemen Kesehatan R.I. Dirjen PPM dan PLP.; 1999.

19. Almatsier S. Prinsip Dasar Ilmu Gizi. Jakarta: PT Gramedia Pustaka Utama; 2010.

20. Furkon LA. Modul 1 Ilmu Kesehatan dan Gizi "Mengenal Zat Gizi Makro." Banten: Universitas Terbuka; 2017.

21. Supariasa IDN, Bakri B, Fajar I. Penilaian Status Gizi. 2nd ed. Jakarta: EGC; 2016.

22. Sjarif DR. Buku Ajar Nutrisi Pediatrik dan Penyakit Metbolik. Jakarta: Badan Penerbit IDAI; 2014.

23. Nasar SS, Djoko S. Penuntun Diet Anak. 3rd ed. Jakarta: Badan Penerbit Fakultas Kedokteran Universitas Indonesia; 2017.

24. Tufa EG, Dake SK, Bekru ET, Tekle HA, Bobe TM, Angore BN, et al. Magnitude of wasting and underweight among children 6-59 months of age in Sodo Zuria District, South Ethiopia: a community based cross-sectional study. BMC Res Notes [Internet]. 2018 Dec 3;11(1):790. Available from: https://bmcresnotes.biomedcentral.com/articles/10.1186/s13104-018-3880-x 